\title{
The Placement Position of Hollow Cores in the Ideal Longitudinal Direction on the Reinfoced Concrete Beam
}

\author{
Sumiati $^{1, *}$ Mahmuda $^{1}$ Ahmad Syapawi ${ }^{1}$ \\ ${ }^{I}$ Department of Civil Engineering, State Polytechnic Sriwijaya, Indonesia \\ ${ }^{*}$ Corresponding author. Email: sumiati@polsri.ac.id
}

\begin{abstract}
Reinforced concrete beam is a structure that designed to restrain the bending moment, torsional moment, axial force and shear force, made of concrete which functions to withstand compressive strength and reinforcing steel to withstand flexural strength. However, of reality many other utilities as: water supply, sewerage, power lines, telephone cables, air conditioning systems, computer networks and so on, attached to the beam, so that it looks less aesthetic and protected. If the utility is placed in the block space by making a hole in the beam in the compressed area, it will reduce the compression strength. Therefore, it will be investigated the strategic position of the hollow cores longitudinal direction, so that the strength of the beam is not reduced, it can function as a structure that holds and distributes the loads that work on it, and as a support for utility. The purpose of this research was to make a reinforced concrete beam, apart from it has function as a structure that holds and distributes the loads that work on it, it also has function as a utility support by utilizing the space in the structural beam. To achieve the purpose of this research, 10 specimens of 100x150x750 $\mathrm{mm}$ beam with 4 variations in placement of hollow cores made of Polyvinyl Chloride with 1 inch diameter, which is compared to a beam without a hollow core. Testing of reinforced concrete beams is carried out based on the standard simple beam with centre-point loading, after curing for 28 days to obtain data: ultimate load, modulus of rupture (MOR) that can be withheld by blocks, modulus of elasticity (MOE) and cracked fields that occurs beam. Based on the results of the research has been undertaken, it indicated that the position of hollow care that is put on the tensile zone in the longitudinal direction of the beam increased the stiffness (MOE) on the beam, ultimate load and modulus of rupture (MOR) which the beam can withstand. However, a reinforced Concrete beam with a hollow core of $100 \mathrm{~mm}$ from the top of the beam decreased stiffness. The collapse that occurred in the reinforced concrete beam with a hollow core started from the cracked at the very bottom of the beam, in the middle of the span in the tensile zone.
\end{abstract}

Keywords: hollow core, modulus of rupture,

\section{INTRODUCTION}

Concrete is a mass made from a mixture of cement, water and aggregate. Aggregate consists of fine aggregate (sand), and coarse aggregate (crushed stone). The structure of beam is made of concrete or other materials are basically planned to accept the bending moment, torsional moment, axial force, shear force or a combination of these forces. Concrete has advantages including high compressive strength, resistance of corrosion and resistance of fire, but it also has disadvantages such as flexural strength is only $10-15 \%$ of its compressive strength. Meanwhile, reinforcing steel has high flexural strength. Hence, to withstand the bending moment and force that will work on the beam, reinforcing steel is used so that a building construction method is called as reinforced concrete.

The structure of high-rise buildings, bridges, overpasses that use reinforced concrete as the forming material, it usually requires utility networks such as: water supply, sewerage, power lines, telephone cables, air conditioning systems, computer networks and so on. This network placement is usually only attached to the beam or placed at the top of the ceiling for buildings. In this regard, it certainly seems less aesthetic and less protected.

Creating the holes in reinforced concrete beam can reduce the weight of the beam, which certainly it can save 
concrete material, so that the cost of making concrete becomes more economical. The lighter weight of the concrete can also mitigate the danger of an earthquake. However, the reduced cross-sectional area of the beam, it has function to withstand the compressive strength that will work together with the reinforcement to restrain the bending moment and certainly it will also decrease.

The position of placing the hollow core on the beam and the material that is used, it will certainly greatly affect the flexural strength that the beam can withstand. If it is put in compression zones (in the compressed area), thus, it will affect on the compressive strength. Whereas, if it is placed in tensile zones, it will not affect the flexural strength. This is due to the flexural strength of the concrete, which is only $10-15 \%$ of its compressive strength, it is not optimally utilized. Research [1], by placing holes in compression zones, neutral axes and tensile zones in the direction of longitudinal beams and the diameters of hole that vary, it is found that if the holes are placed in compression zones, it will reduce the flexural strength of beams. Meanwhile, if it is placed in tensile zones, it will not affect the flexural strength of beams. Flexural strength also affects the hole diameter, the larger of the hole diameter, the smaller of the flexural strength that can be resisted by the beam.

Many previous studies have been carried out, including: research [2], using reinforced concrete beams in the size of $(150 \times 150 \times 600) \mathrm{mm}$ with the diameter of tensile steel is $8 \mathrm{~mm}$ and the variation of pipe diameter is $1 / 2$ inch; 1 inch; $1 \frac{1}{2}$ inch and reinforced concrete beams without hollow cores. The results of the research on the relationship between flexural strength and variations in pipe diameter indicate that the larger of the diameter of the pipe, the smaller of the flexural strength that can be withstood by the beam.

Research [3], using Polyvinyl Chloride Pipe and Galvanized Iron Pipe vary on $1 \varnothing 63.5 \mathrm{~mm}$ and $2 \varnothing 31.75$, placed in tensile zones ( $50 \mathrm{~mm}$ below the neutral axis) with cross section $(150 \times 200) \mathrm{mm}$, it is found that flexural the strength of beams using Galvanized Iron Pipe $1 \varnothing 63.5 \mathrm{~mm}$ is greater when compared to beams without hollow cores and beams with Polyvinyl Chloride Pipe. Beams with hollow core Polyvinyl Chloride Pipe have lower bending strength when it is compared to beams without holes. Beams use the holes for Polyvinyl Chloride Pipe and Galvanized Iron Pipe with holes $1 \varnothing 63.5 \mathrm{~mm}$ and those have a higher flexural strength than those that use holes $2 \varnothing 31.75 \mathrm{~mm}$.

Research [4], the size of beams is $(150 \times 150 \times 1400)$ $\mathrm{mm}$, with varying pipe diameters $\varnothing 32 \mathrm{~mm}, \quad \varnothing 40 \mathrm{~mm}$ and $\varnothing 50 \mathrm{~mm}$ that placed in compression zones along the beam (longitudinal direction of the beam), it is found that the forces that can be retained, it decreases along with the increase of diameter of the hole when it is compared to a beam without a hollow core.
Based on [5], that making holes in reinforced concrete beams is only allowed about $4 \%$ of the cross-sectional area of reinforced concrete.

In this research, we will use Polyvinyl Chloride Pipe which is placed in the longitudinal direction of the beam with various placement positions, so that an alternative design will be obtained by utilizing the space in the structural beam. Apart from it has function as a structure that holds and distributes the loads that work on it, the beam can also has function as a utility support.

The main purpose of this research was to obtain the placement position of hollow cores in the ideal longitudinal direction on the reinfoced concrete beam, by way of analyzing the ultimate load and modulus of rupture (MOR) that could be resisted by the beam and also the stiffnees/modulus of elasticity (MOE) and cracked fields that occured in the beam, so that an economical beam structure will be obtained without reducing the function of the beam to carry out the loads, mitigate earthquakes and has aesthetic value.

\section{METHODOLOGY}

This research was undertaken based on seeing the cases in the field, where the electrical installation is attached to the beam (Figure 1.a) and the sewerage installation is also sticked to the beam (Figure 1.b).

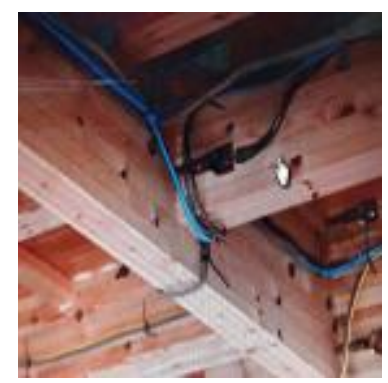

a.Electrical installations

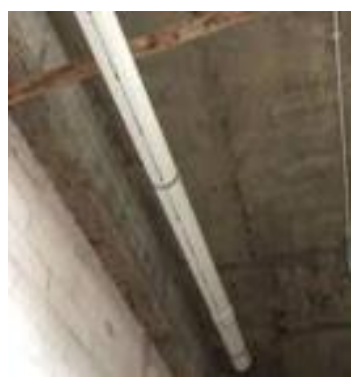

b. Sewerage installations
Figure 1. Electrical installations and sewarage installations attached to the beams

Therefore, in order to achieve the objectives of this study, 10 specimens of $100 \times 150 \times 750 \mathrm{~mm}$ were made, in which 2 specimens were made for each variation of pipe placement. Testing of reinforced concrete beams was carried out based on the standard simple beam with center-point loading [6], after curing for 28 days. Reinforced concrete beams were planned to have a compressive strength of $\mathrm{fc} \pm 20 \mathrm{MPa}$. The concrete forming materials consisted of: fine aggregate (sand) is originated from the Musi river. coarse aggregate (crushed stone) comes from Bojonegoro and Portland cement of type I under the brand name of Baturaja. To get the targeted compressive strength, a mix design was carried out first based on [7], the material will be used, it must be tested for physical properties, including: Sieve Analysis 
of Fine and Coarse Aggregates [8], Relative Density (Specific Gravity) and Absorption of Coarse Aggregate [9], Relative Density (Specific Gravity) and Absorption of fine Aggregate [10], Materials Finer than 75- $\mu \mathrm{m}$ (No. 200) Sieve in Mineral Aggregates by Washing [11], Bulk Density ("Unit Weight") and Voids in Aggregate [12], Organic Impurities in Fine Aggregates for Concrete [13], Determination of aggregate crushing value (ACV) [14], Abrasion and Impact in the Los Angeles Machine [15], Density of Hydraulic Cement [16 ] and Standard Test Method for Soundness of Aggregates by Use of Sodium Sulfate or Magnesium Sulfate [17]. Concrete compressive strength test specimens were made in accordance with the standard [18], as many as 3 samples were cylindrical with a diameter of $15 \mathrm{~cm}$ and a height of $30 \mathrm{~cm}$, tested after being cured for 28 days. Reinforcing steel used to make beam, it has a tensile strength of fy \pm $240 \mathrm{MPa}$. Flexural steel $2 \varnothing 10$, compressive steel $2 \varnothing 6$, shear steel $\varnothing 6-50$ (Figure 2.a). The placement position of pipe, it varies with distance: reinforced Concrete beam with hollow core $40 \mathrm{~mm}$ (Figure 2.b); reinforced Concrete beam with hollow core $60 \mathrm{~mm}$ (Figure 2.c); reinforced Concrete beam with hollow core $80 \mathrm{~mm}$ (Figure 2.d) and reinforced Concrete beam with hollow core $100 \mathrm{~mm}$ (Figure 2.e) from the top of the beam section. Based on calculations, the location of the hole is located below the neutral axis (tensile zone).

Based on the Indonesian National Standard (SNI 060084-2002), the polyvinyl Chloride Pipe used for water supply installations has a diameter of $1 \mathrm{inch}$, has a modulus of elasticity of $\pm 3000 \mathrm{MPa}$, tensile strength of $50-80 \mathrm{MPa}$ and specific gravity of $\pm 1.4 \mathrm{gr} / \mathrm{cm} 3$.

The test results of a simple beam with center-point loading beams without a hollow core and a beam with a hollow core placement position in varying longitudinal directions would be calculated using the formulas (1), (2) and (3), would be illustrated in the form of relation between Modulus of Rupture and modulus of elasticity histogram of specimens and form of relation between load-displacement curves of specimens, it would be analyzed through the ultimate load and flexural strength that the beam can withstand as well as the stiffness and cracked fields that occured in the beam, so that the conclusions of this research will be obtained. The modulus of rupture (MOR) and modulus of elasticity (MOE) of the simple beam test with center-point loading, used the following formula (ASTM C293/C293M-16):

$$
\begin{aligned}
& \text { MOR }=\frac{a P \cdot L}{2 \cdot b \cdot h^{2}} \\
& \text { MOE }=\frac{\sigma}{g} \quad \text { MOE }=\frac{\sigma}{g} \\
& \text { (2) } \\
& \sigma=\frac{P}{A} ; \varepsilon=\frac{\mathbb{A L} L}{L_{\varphi}}=\frac{L_{1}-L_{0}}{L_{\varphi}}
\end{aligned}
$$

where:

$\mathrm{MOR}=$ Modulus of rupture $(\mathrm{MPa})$

$\mathrm{MOE}=$ Modulus of elasticity $(\mathrm{MPa})$

$\sigma \quad=$ Stress $(\mathrm{MPa})$
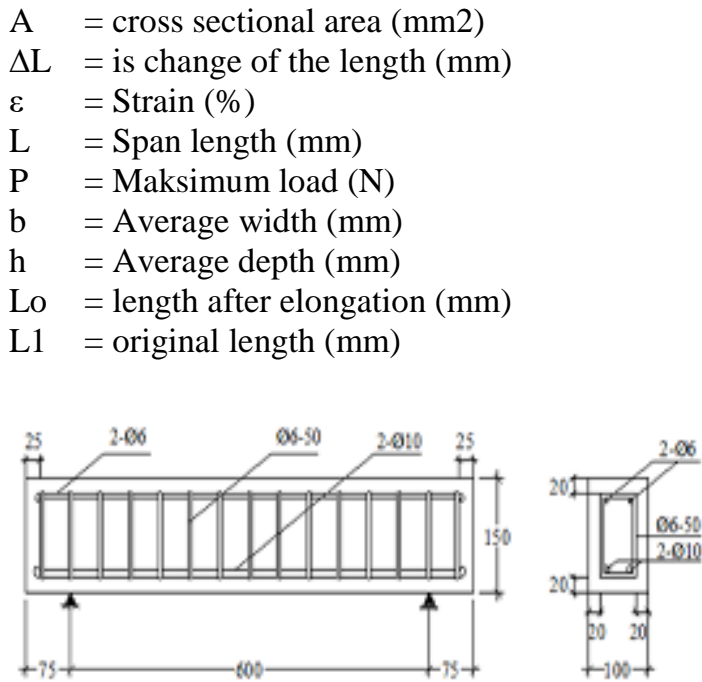

a. Reinforced Concrete beam (RC)
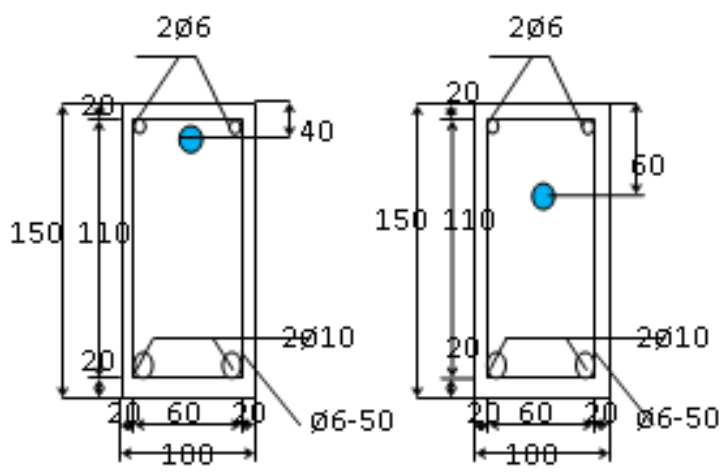

b. $\mathrm{RC}-40$

c. $\mathrm{RC}-60$
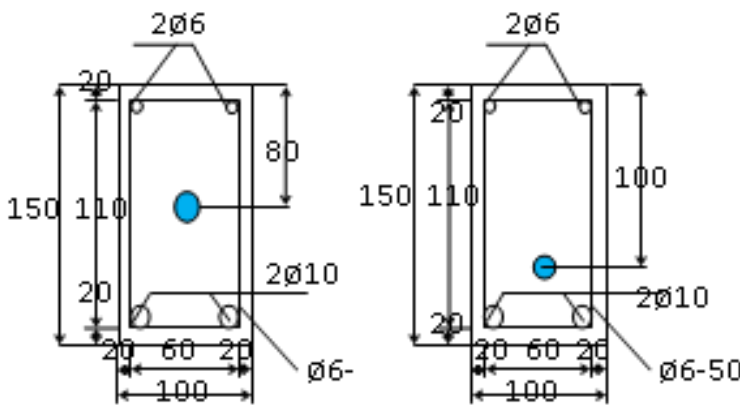

d RC-80

e. $\mathrm{RC}-100$

Figure 2. Detail reinforced steel concrete beams with hollow core position.

\section{RESULTS AND DISCUSSION}

The results of testing the physical properties of concrete forming materials can be seen in Table 1 . The materials used are: Fine aggregate (sand) is included in zone 3 (finely graded sand), coarse aggregate has a maximum grain size of $20 \mathrm{~mm}$. Composition of cement: fine aggregate (sand): coarse aggregate (crushed stone) calculation results of mix design concrete obtained 
ratio is $1: 1.3: 1.7$, with a cement water ratio $=0.5)$.

(w/c

Table 1. Results Testing of physical properties of coarse/fine aggregates and cement

\begin{tabular}{|c|c|c|c|c|}
\hline \multirow[b]{2}{*}{ Testing } & \multicolumn{3}{|c|}{ Result Test } & \multirow[b]{2}{*}{ Unit } \\
\hline & Sand & $\begin{array}{c}\text { Grave } \\
1\end{array}$ & cement & \\
\hline Sieve Analysis & $\begin{array}{c}\text { Zone } \\
3\end{array}$ & $\begin{array}{c}\operatorname{Max} \\
20\end{array}$ & - & \\
\hline $\begin{array}{l}\text { Specific } \\
\text { gravity Bulk }\end{array}$ & 2.14 & 2.70 & 3.0 & \\
\hline $\begin{array}{l}\text { Specific } \\
\text { gravity } \\
\text { saturated- } \\
\text { surface-dry } \\
\text { (SSD) }\end{array}$ & 2.21 & 2.74 & - & \\
\hline Absorption & 2.79 & 1.34 & - & $\%$ \\
\hline $\begin{array}{l}\text { Materials Finer } \\
\text { than } 75 \mu \mathrm{m}\end{array}$ & 2.51 & 1,09 & - & $\%$ \\
\hline Unit Weight & 1302 & 1401 & - & $\mathrm{kg} / \mathrm{m}^{3}$ \\
\hline $\begin{array}{l}\text { Aggregate } \\
\text { crushing }\end{array}$ & - & 11,52 & - & $\%$ \\
\hline $\begin{array}{l}\text { Aggregate } \\
\text { abrasion }\end{array}$ & - & 15,18 & - & $\%$ \\
\hline Fine Modulus & 2.98 & 7.71 & - & $\%$ \\
\hline Soundnees Test & - & 2.08 & - & $\%$ \\
\hline $\begin{array}{l}\text { Organic } \\
\text { Impurities }\end{array}$ & non & - & - & $\%$ \\
\hline
\end{tabular}

Compression strength test results for 3 concrete cylinder samples obtained $\mathrm{fc}=20.22 \mathrm{MPa}$ and density $2200 \mathrm{Kg} / \mathrm{m} 3$. The weight of a concrete beam with a hollow core was reduced by $\pm 4 \%$ from a beam without a hollow core.

Data from the ultimate load test, Modulus of elasticity, Modulus of rupture reinforced concrete simple beam with center-point loading with various pipe placement positions can be seen in Table 2. The results of flexural strength testing on the relationship between displacement and ultimate load can be seen in Figure 3, where the ultimate load and flexural strength/modulus of rupture that can be detained by the beam, it has the highest increase in RC-80 (Fig. 2.d) beams by 74\%, RC60(Fig. 2.c) beams are $61 \%$, RC-40 (Fig. 2.b) beams are $50 \%$ and RC-100 (Fig. 2.e) beams are only $5 \%$ compared to reinforced concrete without holes(Fig. 2.a). This can occur because the position of the pipe placement is located in the tensile zone (below the neutral axis), so that the reduced cross-sectional area of the concrete, it does not affect the compression strength that will work together with the reinforced steel in carrying the load and bending moment.

Table 2. Summary of Ultimate Load, MOR and MOE

\begin{tabular}{|c|c|c|c|c|}
\hline $\begin{array}{c}\text { No. } \\
\text { specimen }\end{array}$ & $\begin{array}{c}\text { distance } \\
\text { from the } \\
\text { top of the } \\
\text { beam }\end{array}$ & $\begin{array}{c}\text { Ultimate } \\
\text { Load } \\
(\mathrm{N})\end{array}$ & $\begin{array}{c}\text { MOR } \\
(\mathrm{MPa})\end{array}$ & $\begin{array}{c}\mathrm{MOE} \\
(\mathrm{MPa})\end{array}$ \\
\hline
\end{tabular}

\begin{tabular}{|c|c|c|c|c|c|}
\hline & $\mathrm{mm}$ & Fig & & & \\
\hline $\mathrm{RC}-1$ & \multirow{2}{*}{0} & \multirow{2}{*}{ 2.a } & 28,000 & 11.20 & 12,89 \\
\hline $\mathrm{RC}-2$ & & & 26,880 & 10.75 & 23,57 \\
\hline RC-40A & \multirow{2}{*}{40} & \multirow{2}{*}{ 2.b } & 41,330 & 16.53 & 39,09 \\
\hline RC-40B & & & 40,848 & 16.34 & 41,61 \\
\hline RC-60A & \multirow{2}{*}{60} & \multirow{2}{*}{ 2.c } & 49,243 & 19.70 & 48,81 \\
\hline RC-60B & & & 39,258 & 15.70 & 39,99 \\
\hline RC-80A & \multirow{2}{*}{80} & \multirow{2}{*}{$2 . \mathrm{d}$} & 50,283 & 20.11 & 17,92 \\
\hline $\mathrm{RC}-80 \mathrm{~B}$ & & & 45,024 & 18.01 & 39,49 \\
\hline RC-100A & \multirow{2}{*}{100} & \multirow{2}{*}{ 2.e } & 22,440 & 8.98 & 27,98 \\
\hline RC-100B & & & 35,113 & 14.05 & 35,28 \\
\hline
\end{tabular}

Based on the Whitney stress block, that: compression concrete under the neutral axis does not really affect the ultimate strength of a beam, because the strength below the neutral axis is dominated by the tensile strength which is fully accepted by reinforced steel. Although compression concrete under the neutral axis is neglected, it also plays a role as a medium for transferring stress between the compression zone to the tensile zone. The installation of polyvinyl Chloride Pipe, which replaces this role, it can increase Flexural strength due to polyvinyl Chloride Pipe has a modulus of elasticity of \pm $3000 \mathrm{MPa}$ and tensile strength is $50-80 \mathrm{MPa}$, where the tensile strength of concrete used in this research is merely $\pm 2 \mathrm{MPa}$. The stiffness of the beam can be seen from the slope of the curve in relation to the load and beam displacement (Figure 3). The steeper the slope of the curve, so then the beam is more likely to be the stiffness, or vice versa. Inertia moment is the tendency of an object to rotate about its axis while carrying a load. The inertia moment of a section greatly affects flexural strength, shear strength and torsion strength.

In Figure 4 can be seen that: the biggest of the increase in stiffness/modulus of elasticity occurs in RC60 (Fig. 2.c) beams are 144\%, followed by RC-40 (fig. 2.b) beams of $121 \%$, RC-80(Fig. 2.d) beams are $57 \%$, while in RC-100(Fig. 2.e) beams experience the decrease of stiffness and it gains $57 \%$. The stiffness of the beam which decreases, it can be caused by reduced moment of inertia and tension stiffening in the beam section. If there is a hollow core in the beam, then the stiffness tensile zone (stiffness in the tensile area) of the concrete, it will decrease so that the modulus of elasticity will also decrease when compared to a beam without a hollow core. 


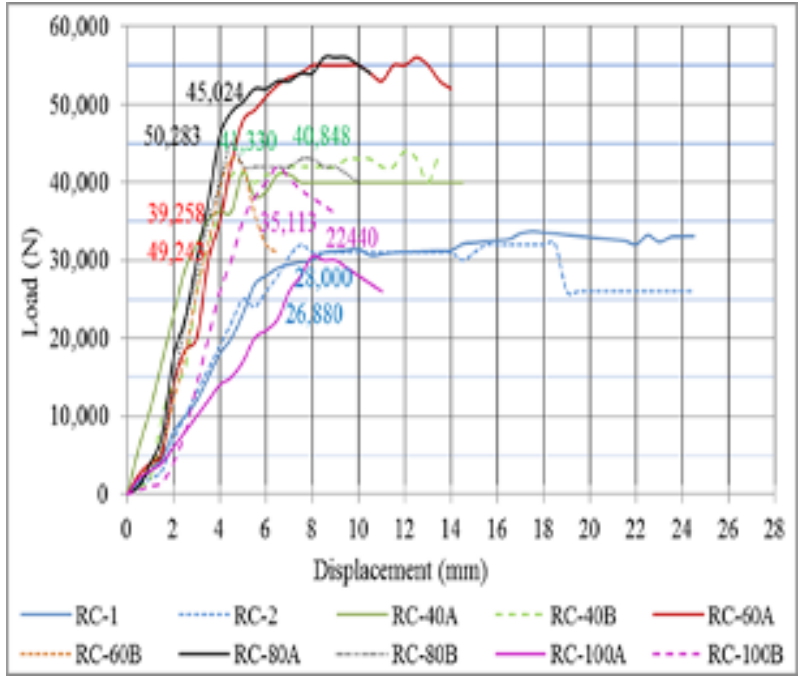

Figure 3. Relation between load-displacement curves of specimens

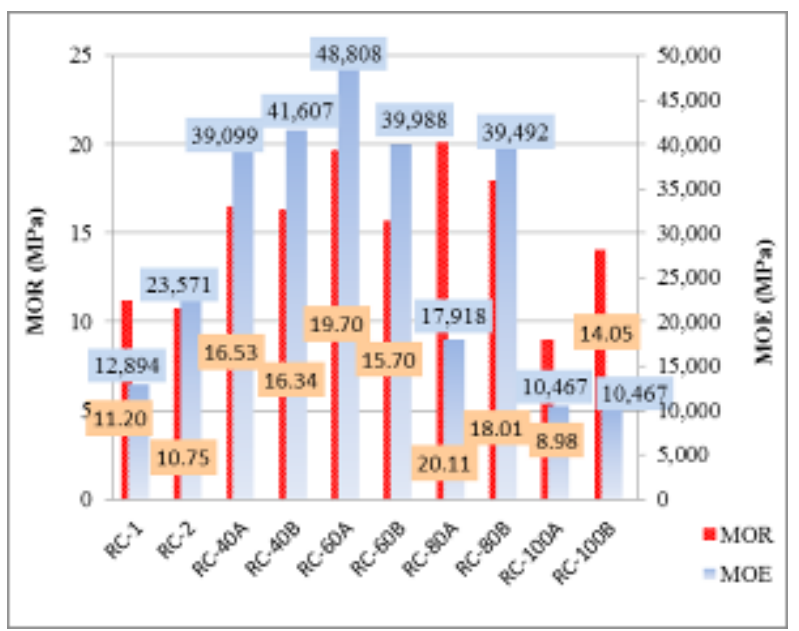

Figure 4. Modulus of Rupture and Modulus of elasticity

Dealing with the observations when testing the flexural reinforced concrete beam until the load has been decreased, it can be observed that the crack pattern that occurs in the reinforced concrete beam with the placement of the hollow core in the longitudinal direction varies in the beam can be seen in (Figure 2.a, 2. b, 2.c, 2.d and 2.e), where the crack patterns that occur can be seen in (Figure 5.a, 5.b, 5.c, 5.d and 5.e). The crack pattern that occurs in all specimens is tensile crack (flexural crack). Flexural cracks occur in the tensile strees starting from the very bottom of the beam in the middle of the span and spreading upwards, followed by other cracks, it is still in the tensile area.

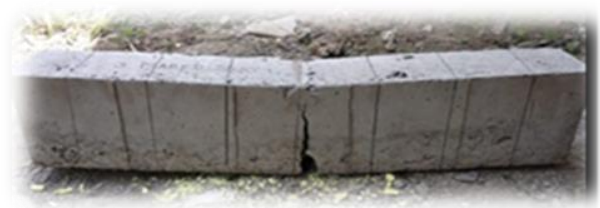

a. RC beam

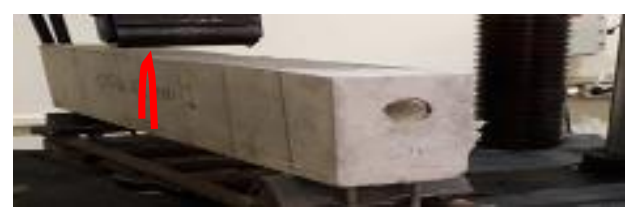

b. RC-40 beam

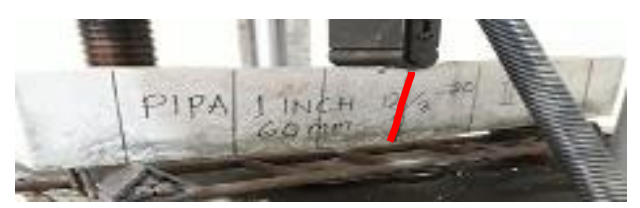

c. RC-60 beam

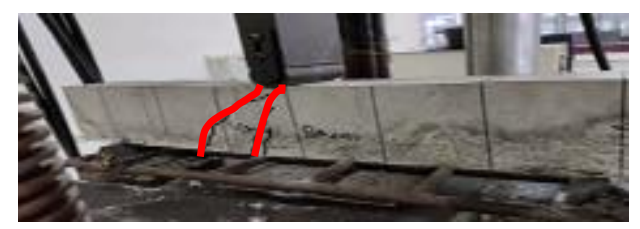

d. RC-80 beam

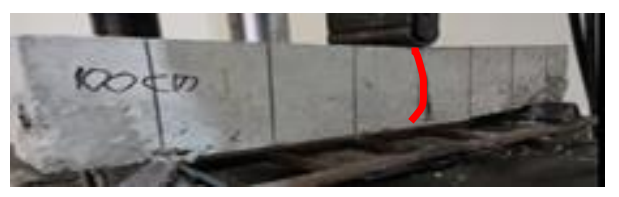

e. RC-100 beam

Figure 5. Failure modes and crack patter ns of specimens

\section{CONCLUSION}

Based on the research that has been conducted, it can be concluded that: The placement position and the hollow core material used, it greatly affected on the ultimate load and modulus of rupture (MOR) that could be held by the beam and the value of stiffness (MOE) on the beam. It is better, if the position of the hole placement is in the tensile area below the neutral axis, because it does not reduce the strength of the beam.

The collapse that observed in reinforced concrete beams and reinforced concrete beams with hollow cores, starting from the cracked at the very bottom of the beam, in the middle of the span in the tensile area. 


\section{REFERENCES}

[1] Arun Murugesan, Arunachalam Narayanan, Influence of a Longitudinal Circular Hole on Flexural Strength of Reinforced Concrete Beams, Practice Periodical on Structural Design and Construction, American Society of Civil Engineers, 2017, volume 22, issue 2, May-2017.

[2] Million Tandiono H. Manalip dan Steenie E. Wallah, The Effect of Pipe Area Variations on Reinforced Concrete Beam Elements on Flexural Strength, Journal Sipil Statik, 2017, Vol.5, No.2, April, pp. 83-94.

[3] G. Balaji, R. Vetturayasudharsanan, Experimental investigation on flexural behaviour of RC hollow beams, Materials Today: Proceedings, 2019, journal homepage: www.elsevier.com/locate/matpr pp.1-5.

[4] Bibi. M Jacob dan Bincy S., Parametric Study of Longitudinal Hollow Steel Fibre Reinforced Concrete (SFRC) Beams, IOP Conf. Series: Materials Science and Engineering 396, 2018, pp.18.

[5] Aci Committee 318, Building Code Requirements for Structural Concrete (ACI 318-95) and Commentary (ACI 318R-95), american concrete institute, Farmington Hills, 1995.

[6] ASTM C293/C293M-10, Standard Test Method for Flexural Strength of Concrete (Using Simple Beam With Center-Point Loading)", ASTM International, West Conshohocken, 2010, PA, www.astm.org

[7] BS-Concrete Mix Design (DOE), The Design of Normal Concrete Mixes, British Standard Institution, 1988.

[8] ASTM C136/C136M-14, Standard Test Method for Sieve Analysis of Fine and Coarse Aggregates, ASTM International, West Conshohocken, PA, 2014.

[9] ASTM C127-15, Standard Test Method for Relative Density (Specific Gravity) and Absorption of
Coarse Aggregate", ASTM International, West Conshohocken, 2015.

[10] ASTM C128-15, Standard Test Method for Relative Density (Specific Gravity) and Absorption of Fine Aggregate, ASTM International, West Conshohocken, PA, 2015.

[11] ASTM C117-17, Standard Test Method for Materials Finer than 75- $\mu \mathrm{m}$ (No. 200) Sieve in Mineral Aggregates by Washing”, ASTM International, West Conshohocken, 2017.

[12] ASTM C29 / C29M-17a, Standard Test Method for Bulk Density (Unit Weight) and Voids in Aggregate, ASTM International, West Conshohocken, 2017.

[13] ASTM C40-04, Standard Test Method for Organic Impurities in Fine Aggregates for Concrete, ASTM International, West Conshohocken, PA, 2004.

[14] BS 812-110, Methods for determination of aggregate crushing value (ACV), British Standard Institution, 1990.

[15] ASTM C131/C131M-14, Standard Test Method for Resistance to Degradation of Small-Size Coarse Aggregate by Abrasion and Impact in the Los Angeles Machine, ASTM International, West Conshohocken, 2006.

[16] ASTM C188-17, Standard Test Method for Density of Hydraulic Cement, ASTM International, West Conshohocken, 2017.

[17] ASTM C88/C88M-18, Standard Test Method for Soundness of Aggregates by Useof Sodium Sulfate or Magnesium Sulfate, ASTM International, West Conshohocken, 2018.

[18] ASTM C873/C873M-15, Standard Test Method for Compressive Strength of Concrete Cylinders Cast in Place in Cylindrical Molds, ASTM International, West Conshohocken, 2015. 